Portland State University

PDXScholar

2014

\title{
Traversing the United States-Mexico Border: Gender and Kinship in Migrant Families
}

Patrick S. Harhai

Portland State University

Follow this and additional works at: https://pdxscholar.library.pdx.edu/honorstheses

Let us know how access to this document benefits you.

\section{Recommended Citation}

Harhai, Patrick S., "Traversing the United States-Mexico Border: Gender and Kinship in Migrant Families" (2014). University Honors Theses. Paper 57.

https://doi.org/10.15760/honors.65

This Thesis is brought to you for free and open access. It has been accepted for inclusion in University Honors Theses by an authorized administrator of PDXScholar. Please contact us if we can make this document more accessible: pdxscholar@pdx.edu. 
Traversing the United States-Mexico Border: Gender and Kinship in Migrant Families

\author{
by \\ Patrick S. Harhai \\ An undergraduate honors thesis submitted in partial fulfillment of the \\ requirements for the degree of \\ Bachelor of Arts \\ in \\ University Honors \\ and \\ Social Science
}

Thesis Adviser

Dr. Michele R. Gamburd

Portland State University

2014 
Traversing the United States-Mexico Border 


\section{Table of Contents}

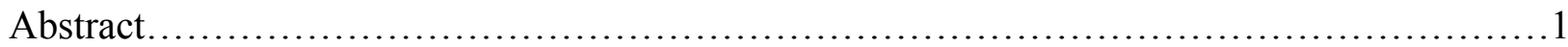

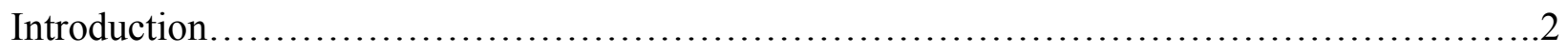

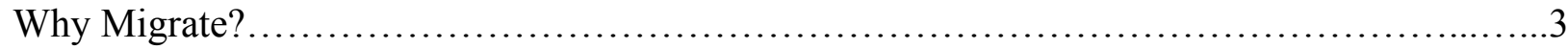

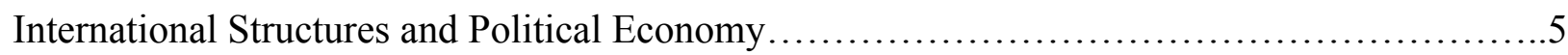

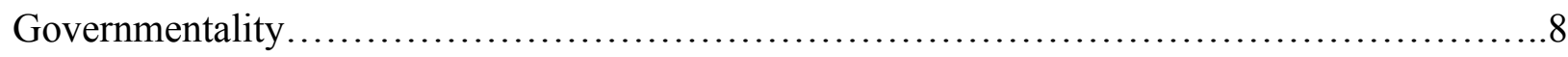

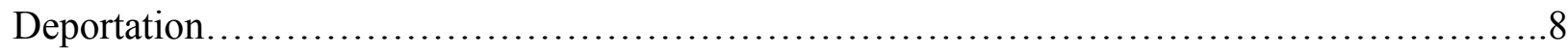

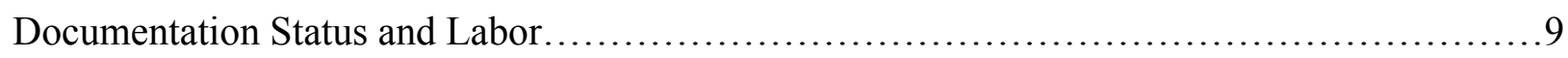

Gender Theory...................................................................

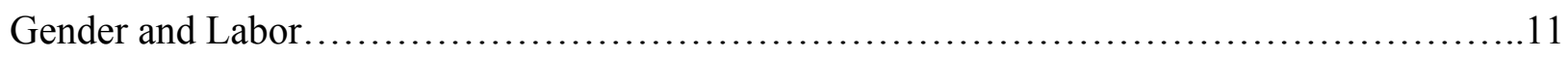

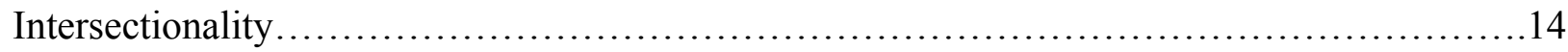

Gender and Race............................................................ 14

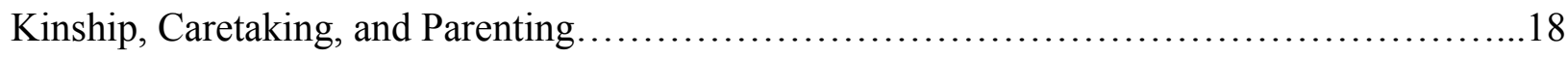

Marriages and Gender...........................................................22

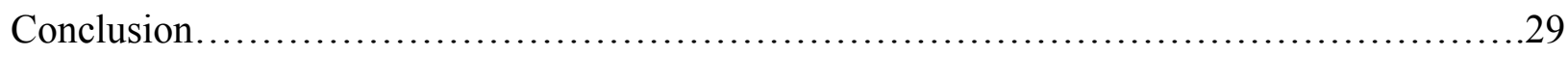

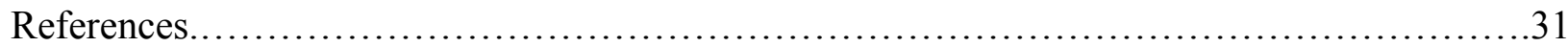

Acknowledgements............................................................ 34 


\begin{abstract}
$\underline{\text { Abstract }}$
This paper explores the process of gender and kinship reconfiguration during transnational migration. Transnational migrants shift and adapt the ways in which they fulfill the cultural responsibilities of kinship and gender. This study focuses on Latin American migrants and their kin networks on both sides of the U.S.-Mexico border. Although themes of global economic, trade, and immigration are present, the focus is migration in a western context. Drawing on published ethnographies, I use data collected by anthropologists and other social science researchers in the past decade and a half to elucidate the ways in which governmental bodies control and incite migration. Transnational migration causes alterations to the methods of fulfilling kinship and gender responsibilities. The findings of this study are highly relevant in terms of creating a cross-cultural understanding of how and why people migrate to the United States.
\end{abstract}




\section{Introduction}

In 2014, as news of immigration reform figures prominently in the media and politics, we need to conceptualize how and why people undergo shifts of location. We must not think people move across borders and live the same lives as before. Indeed, the social and economic environment is different, not to mention things like language and cultural misunderstanding. Transnational actors re-imagine and reconfigure the ways that they interact with cultural responsibilities of gender and kinship to adapt to the constraints of migration. Kinship networks on both sides of the Untied States- Mexico border undergo sometimes drastic shifts in their dynamics and functions as a result of migration. International structures maintain a hegemonic role in social organization; as a side effect people in transnational flux experience reconfigurations of identity. Why do people migrate and face unprecedented challenges to existing norms of kinship and gender, and in doing so, face extreme risks such as death? Structural adjustment programs, free trade agreements, and immigration policies drastically affect the lives of individuals. Global economic, immigration, and trade policies have rendered migration as the key to financial stability in some places. Deportation and precarious labor further complicate the lives of migrants and their kin. These situations leave options for prosperity limited to opportunities abroad.

In this paper, I will first begin by looking at why people migrate. It is clear that limited opportunities exist in Latin America; people move north to prosper. I analyze political economy to show the way international trade structure, immigration and neoliberal labor market policy form techniques of power that influence behavior and create conduct (Rose 1999:52-54). Michele Foucault (1978) and Nickolas Rose (1999) theorize governmentality, the way a government produces and manages behavior in its population. This framework helps to get at 
the incitement to migration. Judith Butler's (1988) theory of gender performativity illustrates that we 'do' our genders through the repetition of bodily styles. This helps us understand how people take on opposite gendered labor and kinship responsibility. Bearing in mind the multiplicity of identity, I also explore Patricia Hill Collins (1998) theory of intersectionality. People do not experience aspects of identity independently, but rather as constructed mutually. Intersectionality helps to shed light on the way that labor markets play on peoples' identities. Finally, I consider the restructuring of kinship in the transnational context vis-à-vis different methods of kinship arrangement around the globe.

This paper is primarily analytical. Anthropological ethnography serves the basis of my data. Jennifer Hirsch's book A Courtship After Marriage Sexuality and Love in Mexican Transnational Families (2003) formed the inspiration for my study of families in the transnational context. I rely particularly on the work of Deborah Boehm $(2008,2009,2011)$, Jason Pribilsky (2004), Michelle Moran-Taylor (2008), Carolina Bank Muñoz (2008) and Melanie Nicholson (2006), among others. Here, I attempt to fuse anthropological scholarship with my interests in gender theory, studies of governmentality, and political economy. Some personal experiences living in Cochabamba, Bolivia supplement insights provided by other scholars.

\section{Why Migrate?}

Migration is the movement of people from one place to another. Here, I discuss the movement of bodies across borders. Although many examples prove specific to lower income migrants from Mexico, the focus centralizes on migration of people from Latin America to the United States. In doing this analysis, we should not conceive of migration as permanent relocation. Such an impression implies rootedness or permanency of bodies after leaving one 
place for another. Numerous scholars (Boehm 2008, Hondagneu-Sotelo and Avila 2007, MoranTaylor 2008, Nicholson 2006, Parreñas 2005, Pribilsky 2004) note that some migrants frame their movements through what Caroline Brettell terms "an ideology of return" (Nicholson 2006:15). To improve the lives of their kin and themselves, people migrate. Despite migrant aspirations to do so, return to the previous country can prove impossible. In this paper I do not consider whether or not migrants make it back to the country of origin, but I must point out that some informants referenced in this study constructed their time in the U.S. as semi-permanent.

People migrate to get ahead, yet this assertion requires unpacking. Migrants aim to provide for their families (Hirsch 2003, Hondagneu-Sotelo and Avila 1997). To provide often means different things. Pribilsky (2004) notes that the success of migration as "a couple's ability to 'get ahead' (salir adelante) with remittances"(2004:316. Others (McKenzie and Menjívar 2001) note building a house as the most salient evidence of a successful migration. Why do migrants risk their lives to come across the sometimes deadly U.S.-Mexico border? First, limited money-making opportunities exist in countries south of the border. Although a mother and father may feed their family with basic staples, they may be unable to purchase or produce certain quality foodstuffs, send their children to school, or pay for medical care. Scholars frequently agree that paying for food, education, and housing index migrant success (Boehm 2008, Gamburd 2008, McKenzie and Menjívar 2011, Pribilsky 2004). Desire for material wealth informs decisions to migrate. As Gamburd (2008) notes, we must reckon with class structure in studies of transnational families. People want access to quality medical care and education, not to mention western markers of affluence such as owning a house or car and wearing northern styles. It seems that migrants cannot fulfill certain basic needs in their home countries because 
larger global structures produce class inequality in the world. Thus, international structures of governance incite global migration.

\section{International Structures and Political Economy}

In this section, I attend to the ways that international economic, immigration, and trade policy intersect to control and produce the flow of transnational migration. Legal structure can manipulate the permeability of borders to ensure specific demographics in the population. If a population is to function the way its government intends, certain policies and procedures must be in place. Governmentality theorizes the way in which governmental bodies manipulate and produce behavior in its population. It also elucidates the mechanisms for control exerted by governmental structures. Contrary to notions of free will, structural availability provides our options and possibilities. The maintenance, modification, and guarantee of migrant laborers happen through governmental interference with immigration policy, economic structures, and labor regulations. At stake here is not only labor market saturation and access to resources, but also the ability for the population to survive. Conservative policies can turn accessible possibilities for immigration into draconian measures that cause people to go hungry, forgo sending a child to school, and live without certain human needs. People obtain work permits, visas, and green cards all the time. Governmental mechanisms of control dictate the possibilities of entry, and the duration of the stay.

A government can produce certain effects through trade and economic policy. The 1993 North Atlantic Free Trade Agreement (NAFTA) opened trade possibilities between Mexico, Canada, and the United States. Many scholars note issues with this trade agreement. The termination of corn subsidies in Mexico put many family farms out of business due to considerable lower prices of U.S. corn, now exported from the U.S. to Mexico (Muñoz 2008). 
Fernandez-Kelly and Massey (2007) and Muñoz (2008) note that the elimination of agricultural subsidies under NAFTA caused a spike in migration. NAFTA is not the only governmental body creating transnational effects.

Regulation of trade opens up foreign markets to U.S. exports. Through the General Agreement on Tariffs and Trade (GATT), now the World Trade Organization (WTO) foreign markets await imports with less restrictions. The United States acted with member states in GATT to reduce taxes on imports and exports (Schaeffer 2003). This created an economic climate across borders that enticed businesses to set up near cheap labor, and also not face import or export tax expenses in bringing their product to another country. International trade policy creates an environment that produces and encourages, yet also makes difficult, transnational migration to the United States. Labor markets in the U.S. benefit from, rely on, and perhaps encourage undocumented labor migration to the United States. International structures produce cheap labor sources; pools of undocumented laborers ensure a cheap labor force. FernandezKelly and Massey write that, "the 1990 Immigration Act added new numerical limitations to the immigration of family members, further reducing the avenues for legal entry" (2007:107). Also "growing U.S. investment south of the border coincided with repressive efforts to limit the crossborder movement of Mexicans, although the number of workers seeking opportunities in the United States had increased as a result of NAFTA” (Fernandez-Kelly and Massey 2007:99). When avenues for legal entry become restricted, undocumented migration increases in prevalence. This may seem paradoxical; however, deeper consideration of the facts suggest otherwise. The legal methods of entering the U.S. have limits, yet the need for laborers is present. People still come to the U.S. for available opportunities. Efforts to curb legal migration help fulfill the need to secure cheap undocumented labor. As will be explored below, 
undocumented migrants indeed earn less money than their documented counterparts. It may be that the United States increased militarization of the border after NAFTA to meet cheap labor source needs. Immigration policy does not only reduce legal migration; it gives rise to undocumented migration. With higher numbers of undocumented migrants, businesses draw from a saturated pool of cheap and readily available labor.

Immigration policy has major effects on circuits of mobility. Noting the risks and costs of bi-national sojourning, Fernandez-Kelly and Massey claim that, "U.S. policies have thus been instrumental in transforming a circular flow of male workers into a settled population of families" (2007:110). Further, Munoz (2008) relates the increased military presence along the border caused many Mexican women and children to stay behind because the journey would be too dangerous. Immigration policies cause people to make decisions concerning how migrants will restructure their physical proximity to kin members, rather than curtail migration. Undocumented migrants may have to remain in the United States, when their original intention may have been to return south of the U.S-Mexico border. Militarization of the border does not keep migrants out; it forces them to migrate without documentation.

Border control may be an important act for bodies of government who want better control over its population. For those migrants who want to maintain lives and relationships on both sides of the border, facing the obstacle of physical mobility is the status quo. Rather than some fantastical life where one works in the U.S. for the benefit of family on the other side, it seems by limiting mobility though policy, the government dictates where people enjoy prosperity. Although increasing the standard of living and mobility on a global scale is an apparent desire considering UN millennium development goals, it is possible that structures of U.S. governance 
need to maintain certain people inside its sovereign boundaries. The government values laborers.

\section{Governmentality}

Deportation

We must consider the tools of government which shape who is in the country and for what purpose. It is a U.S. governmental practice to not deport citizens born in the United States to undocumented parents. Inquiry into the value placed on children whose parents have been deported shows that the government has a stake in composing a population. Boehm nicely summarizes how the state has constant effect on its population because of deportation regimes. She writes, "The doubts and insecurities described by deportees and those without papers who could potentially be deported, those who are, in the language of the U.S. Department of Homeland Security (DHS) (2008) 'deportable' can be traced to the presence of the state in individual lives" (2008:347). And as Rose writes, "to govern is to cut experience... and fears... into being" (1999:31). Thus, governmental power functions in one way through its ability to shape experience. Deportability is a matter of state intervention with the population it possesses. These 'deportable' people and their networks experience global fears of removal.

Mechanisms of power play on play on documentation status. Boehm (2009) explains the ways that deportation creates an environment of fear for all people in immigrant communities. Consider a child born in the United States to undocumented migrants. If the government deports a child's parents, the child faces abandonment, placement in foster care, potential homelessness, or relocation to another country. Although the child is not directly at risk for deportation, he or she will feel the effects of a deportation. This is what Boehm (2009) means when she explains the all encompassing nature of deportation regimes within migrant communities. Everyone, not just undocumented people, must be aware of the effects and dangers of deportation. 
Considering Foucault's conception of the family as having economic duties to fulfill (Foucault 1978), it may be that children of deported parents do indeed serve a role in the U.S. economy. The value for the U.S. of a deported family may be that it leaves behind a child. Although costly in the short term, this child might be valuable in the long run considering his position within future labor markets. What jobs will this child eventually hold? Perhaps the child will not receive an education which allows him or her to be successful in college and therefore joins the labor force to fill a gap in needed blue-collar labor. It seems valuable to have people raised in the U.S. in order for them to absorb our cultural values. The function of governmentality aids the development of a population that serves the purposes of the state.

Documentation Status and Labor

Undocumented workers in the formal economy are precarious (Molé 2010). Precariousness per Molé (2010) describes uncertain and impermanent labor. Precarious workers face abuse because of their social location and role as non-citizens within the labor market. This market offers avenues for employment yet concurrently exposes them to the threat of termination due to immigration status. The ability of the Immigration and Naturalization Service or Immigration and Customs Enforcement to crack down on or turn a blind eye to whatever they want is a function of governmentality tied to distribution of economic resources.

In considering upward mobility and achievement, we must look at workers and their documentation status. Undocumented status limits and hinders upward mobility and achievement for workers in the formal economy. Many scholars (Abrego 2009, Muñoz 2008, Nicholson 2006, Zlolniski 2006) discuss the relation between undocumented status and structural abuse. In his ethnography Janitors, Street Vendors, and Activists, Christian Zlolniski discusses the way companies in Silicon Valley subcontract janitorial work and hire undocumented workers in order to save money. Not only do undocumented workers receive less pay, but when the INS 
announced that it would conduct an audit of their employees documentation "about 400 janitors employed by Service International [a janitorial subcontractor]...were laid of because they lacked work permits" (Zlolniski 2006:67). Particularly distressing about this massive layoff is that the new janitors brought in as replacements also occupied undocumented status (Zlolniski 2006). In this case, clearly that the layoff was only a method of appeasing the INS; if the layoff were representative of real change within the labor demographic, the company would not have turned around and hired all new undocumented workers.

Participating in the formal labor market often means taking on undesirable work and being unable to gain decent treatment in the workplace. Muñoz (2008) explains the way a transnational tortilla company hires undocumented workers to work during less desirable night shifts, making considerably lower wages and facing little possibility of upward mobility. Similarly to the negative conditions at the tortilla factory, oppressive labor conditions in restaurants exist (Nicholson 2006). The U.S.-Mexico border produces a subjectivity based on notions of naturalized citizenship and belonging. This effects treatment of undocumented migrants in the U.S. labor force where they are paradoxically desired, needed, and valued by market interests, yet simultaneously denied the same rights and privileges of documented migrants and non-migrants whom we consider full or real citizens.

For migrants in certain places of employment, limited access to upward mobility exists. Perhaps undocumented migrants working in informal sectors such as drug trafficking or day laboring avoid the same precariousness because they are not subject to a verification of their work permits; although they too may not know when or where the work will manifest. Thus, while working without valid documentation poses challenges to upward mobility, it may be more of an issue when people work in formal sectors of employment. As some migrants face the 
challenges of undocumentation and precariousness, the way they fulfill cultural duties of kinship and gender must shift.

\section{Gender Theory}

Gender and Labor

We must look at how the government achieves power through its production of technologies that create knowledge (Rose 1999). We conceptualize a technology of government as a production of knowledge in order to shape and cause behavior. The state creates the behaviors it desires. By creating certain types of knowledge a government has a specific line of reference to "true" fact that will not be contested by the population because the population comes to internalize these ideas as the only way to be. Gender is a cultural production of knowledge which distributes power along normalized vectors. People are coded to enact their gender in specific ways. Practice theory (Ortner 1989) holds that men and women can and do actively shift their embodiment for gainful means. Butler $(1988,1993)$ would add that gender as inherently performative allows people to put on or take off gender like a removable shell. People always already do their gender; it is possible that people consciously manipulate their positions within taxonomies of identity for gainful means. This practice may be a matter of survival.

Sex and gender as a complimentary system of expression forms a cultural production of knowledge that causes people to police their bodies and behavior in ways that support a culturally specific familial model. Judith Butler sums up this perspective of gender in her claim that there are no shared cultural realties of gender (1988:529). Around the world, we can find drastic variance of how humans are 'doing' gender. For example, Reddy and Nanda (2009) have described the Hijra of India, a population of people born male who become women either physically or symbolically and are characterized as being closer to gods than humans. In the contemporary United States, a growing queer population contains members who may seek to 
blur the lines of a binary male/female culture. For example, a person assigned female at birth may take hormones to appear and sound more masculine, without desiring a penis. Far from the narrative of gender transformation from one end of the binary sex/gender system to the other, some people $d o$ gender by occupying ambiguous space in the middle. This practice exposes people to considerable stigma and backlash. The point here shows that people with sexed bodies can and do take on gendered characteristics which are not associated with their biological sex.

Notions of natural sex/gender where males with penises are masculine, and women with vaginas are feminine, and therefore delegated to certain realms of embodiment, subjectivity, labor and political power form knowledges which allow the state to achieve productive means. This production of knowledge does not mean that no reference point to a trans-historical/transcultural sexed and gendered body exists. In fact, people know and enforce what is right or wrong for gendered and sexed embodiment based on cultural ways of knowing. Considering governmentality and gender performativity, these identities fuse onto the body in an attempt to delegate the population into reproductive roles.

Internal identity encounters a problematic externality in the transnational context. The internal sense of self faces a rupture of continuity when forced to do things that one was not previously expected to do. One has to probe whether or not male/female engagement in opposite gender labor is something people consciously do to change social norms or to make themselves more successful. Boehm (2008) identifies one case, which causes issues for considering the gendered transformations in transnational settings. She notes one of her informants was expected to take over all of the traditionally female gendered responsibilities when her husband brought her from Mexico to the United States. Regardless of her work outside of the home, she still had to cook and clean for her husband, and also three other men from their Mexican 
community who live with them in the U.S. (Boehm 2008:26). This was a way of the male exerting power to prevent himself from having to compromise his masculinity. Before his wife's arrival, he had to engage in feminized labor tasks. The choice to avoid a re-doing of these gendered labor tasks by bringing his wife to the U.S. shows that male power exists and functions in myriad ways. By taking on feminine labor, and then deciding to send for his wife to come and do it for him and other males, this informant asserted his power. Male subjectivity can reproduce and enforce an empowered position by molding and cementing previous ways of distributing gendered labor. It is true that both men and women alike shift and adapt their kinship and gender responsibilities. Nevertheless, problematizing and considering who is able to do this with greater fluidity and how these gendered shifts affect greater possibilities of embodiment, labor, and success for individual actors is necessary.

The gendered characteristics of labor create interesting dynamics for the production of transnational identities. For men and women, it means taking on each other's work when they face spatial separation. In a concise and poignant way, one of Boehm's informants expressed “Now I am a man and a woman!'(2008:16). This statement carries incredible weight considering transnational identity construction. Although this quote may seem comical, it masks a series of transformations that men and women endure while abroad. This includes a discussion of how men must take on the duties of cooking and cleaning or send for a female kin member. Although men do express certain gendered labors as undesirable, larger issues exist pertaining to their work and how it produces their subjectivity in feminized ways. For example, farm work helps to construct many masculine identities in Latin America (Boehm 2008:22). In the United States, migrant men typically find work in the service sector, and feel that insertion into this form of wage labor can be emasculating (Boehm 2008). On the one hand, as noted before, men's status 
as 'good men' often hinges on their willingness to migrate and provide for their families. At the same time, based on traditional notions of men's work, the labor men find in the U.S. may feel emasculating. The fact that they have to cook, clean and do laundry only exacerbates these feelings (Pribilsky 2004). As Butler (1993) makes clear, there is no original, prior or true model of gender. Yet, people value the cultural hegemony of sex and gender continuity, and go to great lengths to enforce these norms. Men have the capability to find new ways of interacting as gendered subjects. They can also choose to revert, as referenced by Boehm's (2008) informant.

\section{Intersectionality}

Gender and Race

Gender, race, and documentation status make up vectors of oppression that can assist or hinder a migrant's success. In this section, it will become clear that although transnational migrants have clear goals they wish to attain, factors related to identity hinder achievement. Humans experience race, class, and gender as overlapping identities that mutually construct one another (Collins 1998). In other words, we experience aspects of identity simultaneously not independently. Transnational migration as a strategy for getting ahead causes people to reconstruct ways of engaging gendered labor tasks. For a father who migrates to pay for daily necessities, how and when will he be able to maintain the same quality of life for his family when he returns to his home country? If the structures that create inequality abroad and coerce people to migrate to the United States remain in place when migrants return, how can migrants continue to prosper without the previous source of income? It is possible that the continued income may not be necessary. If the goal is to put a child through school and build a house, perhaps once these tasks are completed, the lower wage available in the home country could be sufficient. The ability to increase status is allowed for or denied by the same structures that 
exclude or permit individuals from entering the U.S. legally. Who gets ahead is an important question for anthropological investigation concerning political economy.

Men adopt ways of doing gender that include stylized acts falsely associated with femininity. When men move across the border and begin to cook and clean for themselves, adaptation to gendered labor tasks becomes a means of survival. Gender is a site of control because it saliently constructs and regulates our social world. As Butler notes, "Gender is made to comply with a model of truth and falsity which not only contradicts its own performative fluidity but serves a social policy of gender regulation and control" (1988:528). Gender is taken as a natural and given fact without historical specificity; dominant assumptions of gender deny the malleability and flexibility of gender. The ethnographic examples explored in this section have shown how gender can be a gainful tool. Thus, when we think of how people embody and enact their subjectivities, we have to pay attention to gender creativity. Further, when looking at the intersections of race, class, and gender it becomes clear that the privileged subject positions of 'male' and 'beautiful' assist transnational actors.

Achieving the goals of migration can be hindered by the specific identities of migrants. The social location of a migrant will directly inform his or her life experience. Racial ideology limits the options for upward mobility in the United States. In terms of racialization, latinos experience assumptions of lower intelligence. In a survey of the experience of Latinos in the United States, nine out of 11 "participants described a variety of instances in which their intelligence was questioned or they were assumed to be less qualified for jobs"(Rivera, Forquer and Rangel 2010:66). Although this statistic is representative of experiences of Latinos, some male migrants have noted they access on-the-job training in certain industries such as car repair mechanics, which in turn leads to higher pay and job flexibility (Abrego 2009). The dominant 
ideology suggests that Latinos have lower intelligence, yet this has not prevented some men from moving up in select industries. It is important to consider whether men are actively participating in an act of embodiment that allows others to perceive them as more masculine and therefore more able to engage in types of labor which afford upward mobility.

I suspect that Abrego's assertion that some men have access to forms of upward mobility is very much limited to particular industries and only representative of a small portion of migrants and of those, men in specific. Men exclusively access some labor industries, such as car repair. It is significant and revealing of the larger structure of patriarchy that Latino men, rather than women, access job training and education. There are other ways in which women are structurally positioned to have limited access to upward mobility.

The industries that predominantly hire women also pay their workers less. This fact should highlight the unequal treatment of women in the labor market. Abrego highlights the areas of labor that typically attract women noting "domestic, garment and hotel housekeeping industries"(2009:1075). In these industries women report low and inconsistent wages, and checks that may bounce (Abrego 2009:1076). Thus, women receive lower and unreliable pay for their labor. Reflecting back upon intersectionality, while men experience their status as Latino/non-white/male migrants, women face the additional structural reality of being Latina/non-white/female and migrant. The taint of womanhood exposes these sexed people to harsher realities, even though they need to meet the same need: sending remittances, paying rent, caring for children, buying food, et cetera. The combination of racial and gender ideologies trap female migrants at the lower end the of status hierarchy in U.S. society. This maintains a class of people who are exploitable and therefore valuable (yet less expensive) to U.S. labor interests. 
To combat negative structural realities women exploit notions of femininity to get ahead in the workplace despite this unequal environment.

By playing with traditional notions of gender, some women gain job stability. This sheds light on constructions of gender. Munoz (2008) shows how women strategically play with make-up and clothing to appear more woman-like and desirable in their workplaces. Indeed, this has translated to better treatment in factory work on the U.S.-Mexico border. The play with make-up is built on a practice of drag that is meant to exaggerate so-called feminine features of beauty. It is a way that women are able to gain stability in the labor market. As Butler writes, "Drag constitutes the mundane way in which genders are appropriated, theatricalized, worn, and done..." (1993:313). Tinkering with gendered attributes is a conscious practice of self-styling that allows women to exert agency that translates into economic stability. It needs to be noted that not all women look the way men want them to, and therefore who successfully plays with drag in the factory for productivity is limited to cultural conceptions of beauty. ${ }^{1}$

Explorations into agency ask us to reconsider what is at stake in theorizing people as agentive. Agency, the idea of being able to act, that a person has the ability to consciously take part in action, might be simplistic because it places all emphasis on the individual as inherently able to consciously act. As Buffington (2007) shows, not all people have this ability. He suggests we take another look at the intertwined nature of agency and subjectivity to look at the way that people are able to act only through their subject positions. In other words, subjectivity, which names how we are in relation to — summarizing Buffington's use of Mansfield—other beings and structures and environments, is a productive place to start to consider how we act as

\footnotetext{
${ }^{1}$ Munoz (2008) elaborates on how male supervisors exploit female laborers by requireing them to give kisses and go on dates. For the purpose of this argument I will not delve into an analysis of the mysogeny and sexism inherant in this practice. Also, the women who receive privilege from male bosses in this factory typically had lighter skin and were considered more educated.
} 
agents (Buffington 2007:1641). Thus, we cannot have a complete theory of agency without reckoning with the way that agency and subjectivity share a symbiotic relationship. One's subject position determines accessibility to particular forms of agency.

To put to work Buffington's exploration of subjectivity and agency, we must not simply analyze whether or not men and women migrants from Latin America actively make the decision to interact with opposite gendered labor and kin arrangements; rather, we must look to the way that their subjectivities: race, class, gender etc., are determinant of how they are able to act. By failing to do this, we risk displacing the intersections of identity.

\section{Kinship, Caretaking, and Parenting}

The focus so far has centralized on gender, labor, and race. Moving forward, I will discuss the reorganization of kinship responsibilities in the transnational context. This exploration will still include attention to gender, but expand to encompass the ways that people 'do' their kinship responsibilities. I want to draw on notions of 'doing' gender as per Butler, and apply those ideas to 'doing' kinship. ${ }^{2}$ Butler writes "gender is in no way a stable identity or locus of agency from which various acts proceede; rather, it is an identity tenuously constituted in time-an identity instituted through a stylized repetition of acts" (1988:519). Kinship, like gender appears performative in its basis within a repetition of acts. Kinship responsibility like gender responsibility builds itself on cultural notions of proper behavior. I will first focus on caretaking responsibilities before presenting shifts in marriages and intimate networks of people.

In the United States, as in all parts of the world, many specific notions of how caretaking should be done exist. Kinship is widely defined as the relationships between people based on marriage or blood (Stone 2014). In addition to distributing childrearing duties, kinship norms dictate what people must do under the marriage contract. Although it is common for parents to

\footnotetext{
${ }^{2}$ Or, 'undoing'
} 
leave children in daycare situations and with baby-sitters, the upper-class western model relies heavily on biological connections. Societies exist where people of varying biological and social connection raise children. It seems ideal to have multiple individuals helping with childrearing; however, in Latin America, there may be push back from others when a mother leaves a child behind in her pursuit of work outside the home.

Women modify their fulfillment of gendered kinship responsibilities. Nicholson states "rethinking motherhood in a transnational context requires broadening our understanding of what it means to be a 'good mother'"(2006:15). Further, we must keep in mind economic realities, specifically poverty, when we analyze the redistribution of labor in the family (Gamburd 2008:9). When women leave their children in the care of others, women do not abandon their kids; rather, they are simply doing caretaking in new ways vis-à-vis previous historical models.

In Latin America, as in most cultures, in the context of migration and typical day-to-day interaction, caregivers seem appropriate for delegating child rearing tasks (Moran-Taylor 2008). This may conflict with in-group ideology that claims the biological mother should be around more than the caregiver, and that the caregiver is not considered family. Despite its prevalence, the caregiver role is contested and met with skepticism. In Bolivia a caretaker named Lupita ${ }^{3}$ once expressed to me that because the biological mother, Marta, was at work all day and was not doing the day-to-day childrearing, the children were misbehaved. Lupita often related to me in frank terms that this mother was not successful in fulfilling her duties as a mother. A good mother, as per this Lupita, should be around "at least half of the time". Lupita explained that as she could not physically discipline the children, her efforts to punish the children were null. Lupita was around more than Marta, yet not considered family. Interestingly enough, Lupita related to me that she indeed felt like a grandmother to these children despite their misbehaved

\footnotetext{
3 'Lupita' and 'Marta' are pseudonyms.
}

Traversing the United States-Mexico Border 
nature. This model of biologically based kin ties that exclude non-biologically related caretakers is specifically western. Although in the west we still do non-biological kinship via adoption and marriage. In Pacific Island societies, children and families often scatter responsibilities between people of biological and non-biological ties. This does not break ties; rather, it causes people to have a greater community of kin members (Strathern and Stewart 2011). Scholars hold that anyone who is in the "supportive domain"(Strathern and Stewart 2011:9) of children could be considered kin, yet this does not always become practice. And, as in my experience in Cochabamaba, it is clear not everyone feels that caretakers should be family.

It seems to me that this caregiver carried out a majority of the day-to-day child care responsibilities. As such, it may be that Lupita wanted to avoid characterization as someone who failed to properly raise the children. Her expressions about the biological mother may have been a way for her to protect her reputation. Lupita may have been telling me more about herself than Marta in her desire for me to understand why the children were misbehaved. As Lupita could not hit the kids, she could not properly form them as humans. Although it was Lupita's responsibility to care for the children, she would not assume responsibility for their transgressions.

Transnational migration causes kinship responsibilities to be re-conceptualized and altered. When a mother leaves her children under the watch of a caretaker so she can move abroad to work (or even simply go to work in the home country), she takes part in the modification of how she fulfills kinship responsibilities. She is using her agency to perpetuate a reconfiguration of the structure of parenting that would have once denied her the ability to leave her children in the care of others so she can migrate to another country. Hondagneu-Sotelo and Avila (1997) and Nicholson (2006) describe notions of transnational parenting rely upon 
reconfigured notions of what it means to parent. Hondagneu-Sotelo and Avila (1997) add that in Latin American culture expects biological mothers to raise their own children. Methods of providing childcare change as women pursue opportunities abroad.

By migrating, women are fulfilling their role as caretakers of their families in new ways. Nicholson explains women exert agency in new ways by entering the international labor market (2006). Although new conceptions of who raises the children-biological parents or caretakers - have allowed women to challenge how they interact within structures of kinship responsibility, women are by no means failing in the duties of motherhood. As Abrego demonstrates, "transnational mothers...invariably remit higher percentages of their earnings and more consistently than fathers"(2009:1082). Abrego (2009) also shows that some women endure abuse and hardship in order to provide remittance for their children. Is it interesting that women who make less money than men and face more structural barriers to upward mobility are able to send more money more consistently back home? Or, is this a clear reproduction of traditional kinship norms? I argue that this altered structure of motherhood which allows women to migrate to provide, both departs from, and is built on, the traditional norm of women as caretaker. Transnational mothers challenge the way they participate within the cultural configuration of parenting.

Fathers too undergo changes in how they relate to their networks of kin. Traditional notions influence the changes men go through, yet manifest in new ways. Pribilsky (2004) describes the state of parenting in the Andean highlands of Peru. He explains in the past, men based relationships with their children on respect. However, migrating changes the way men interact with their children. In situations where men leave children behind very early in life, they struggle to enforce relationships of respect when they return too much older children (Pribilsky 
2004). One of Pribilsky's informants claims that he is a better father as a result of migration because he builds relationships of loving affection rather than hierarchical respect (2004:330). One form of practice that alters structures of kinship concern adaptations of fatherhood. Male migration may facilitate the shift. Perhaps he had exposure and access to models of parenting and fatherhood that show alternatives to the iron fist patriarch. He may feel more symbolically empowered to be emotional with his children. In the case, his gendered self shifts to include emotionality that may be characterized as feminine. The physical separation of children from their parents represents a major area of transformation concerning kinship norms and responsibilities.

Transnational actors alter methods for fulfilling responsibilities of caregiving and parenting. Migrants also alter the structure of their marriages. We cannot forget the role of governments in forming families. Strathern and Stewart speak of the state of families when explaining how "rights of people to benefits, maintenance, and compensation, and their ability to represent each other or to control each other in various ways, are all legally set out" (2011:9). This is to elucidate that the law mediates rights and responsibilities. Government interference in the family works to decide who gets, does, or is, what. It is a matter of legality that a family can even be constituted in U.S. society. It is important to carry in mind that when people migrate to the United States, they must figure out a way to fit within our structure of kinship organization. Thus, if a family migrates to the U.S. and receive legal recognition and the privileges accorded to 'proper' families, the way they do family needs to coincide with the U.S. way of doing kinship.

\section{Marriage and Gender}

The transformations that take place within marriages connect to shifts in gender roles and ideologies and have much to do with labor responsibility. In a transnational partnership, women and men reconfigure the ways they meet gendered kinship duties. The gendering of public 
space, the division of labor, and notions of proper conduct begin to reflect more clearly a gendered division often realized in ideological terms rather than concrete realty. The traditional make-up of gendered kinship responsibilities in Latin American relationships require that men and women complete certain tasks to provide for their families.

Notions of labor responsibility rest on a pubic/private ideology in which men are permitted to interact in the public sphere and women must take charge of the home domain. While men must bring in money from labor outside the home, women's work is idealized as domestic work within the home such as cooking, cleaning, caring for children, et cetera. However, it is important not to accept that this public/private or domestic/external dichotomy as an impenetrable boundary. It is clear that women operate within both spheres and that the division is not so stark (Lamphere 2007). Indeed, as Hirsch (1999) notes, women in Mexico have always earned money, which would require them to enter the public market. It seems necessary for women to take over farm labor, manage finances, pay debts, or oversee home renovation and construction (Boehm 2008). Thus, women interact within the public sphere even though the public imagination locates women's labor within the home.

Much of this labor involves women taking space in the public sphere. It is not that women have not always occupied this place in public, but that in the transnational context it is done on account of a husband's absence. Women take up the roles of men, at community meetings for example, where they previously did not. A woman's mobility outside of the home is not significant or new; rather, it is simply new that she attend the community meeting in place of her husband. Women form a part of the public/private dichotomy both inside and outside of the home. Female occupation of public space in place of men is a departure from previous traditional responsibilities. 
However, some may claim that women do not occupy this space as themselves; rather, as proxies for their husbands. Womens' bodies indeed take up physical space in a pubic location. Women have a stake in these community meetings. It is not as if at these meetings people treat her as her husband or even her husbands proxy, though she may be simply that. Her occupation of space in the meeting hinges on her female identity, and this identity will dictate the role she plays in the meeting. If she were her husband's proxy, her identity as woman would be erased. Men's traditional responsibilities to their families require that they provide. Characterizations of male masculinity require the ability to provide. Latin American culture expects men to migrate to fulfill their duties as husbands and fathers. Boehm $(2008,2011)$ notes how 'good male' identity requires migration. Religious community leaders reinforce this gender ideology. Boehm observed a priest claiming at a public wedding ceremony that the groom was a "good man" (2008:21) because he would leave home to earn money. This migrant man gained cultural capital because he was going to migrate in order to be able to build a home and provide. In some cases, women often expressed that they felt a link between their husbands' migrations and their responsibilities as men. One wife of a migrant stated, "I don't want us to live apart, but we really don't have any other options. I am pressuring him to go to the other side" (Boehm 2011:99). This is an example of how families position themselves in a transnational context built on traditional notions of man as provider, by expanding and redefining how they fulfill traditional notions of marriage role and responsibility. Kinship norms in Latin America dictate that men and women live together; however, this possibility may end up abandoned in order for couples to pursue opportunity. The editing of marriage role and responsibility to allow for new spatial possibilities in a relationship comprises a collective practice that alters specific aspects of the kinship structure. 
This reimagining of spatial possibilities in marriage separates partners from living together and produces mixed feelings. Although men and women know that they need to seek opportunities abroad, this often comes at a difficult price that requires shifting what it means to be married. Not only do couples not want to live apart, another often undesirable side effect of men migrating north is that male infidelity increases, even in so-called monogamous relationships. Many scholars (Boehm 2008, 2011, McKenzie and Menjívar 2001, Pribilsky 2004) interrogate the presence of infidelity in transnational contexts. Pribilsky explains that when he asked migrant men from Peru which aspect of their lives was hardest to maintain transnationally, it became emergent that remaining faithful was the hardest part (2004:314). One trouble with this new extramarital interaction on the part of men is that women fear complaining about their husbands' activities because they depend on the remittances their husbands send. Boehm (2011) explains that fear of losing remittances as the main reason women will not complain to or about their husbands. Perhaps being abandoned by their absent husbands would be an even greater shame than accepting that men cheat while abroad. In order to maintain transnational ties to their husbands, and successfully get ahead through remittances, widening possibilities for erotic conduct within a marriage and accepting that men might have sexual affairs abroad may be necessary for families in the migratory context.

The fact that men commit infidelity without repercussion reveals a transnationally produced gendered inequality. The tacit acknowledgement on the part of women that this occurs suggests a wider shift in the organization of marriage. Even though monogamous bonds are desired, sought, and created, the practical reality is that these prized relationship forms are not working out to the highest standards of adherence. Society denies certain sexual agency to 
women, whereas men access more sexual freedom. Women, whether abroad or in their home countries, are never given the license to commit adultery.

As I have argued, transformations in kinship and gender are built on and depart from mainstream notions of cultural requisites of individuals. This aspect of gender in the transnational context has not been reconfigured. The lack of sexual agency for women reflects a culture of patriarchy in which women are held to different moral and sexual standards than men. It is as if transnational husbands believe their wives are incapable of having a side sexual outlet without abandoning them. I suggest a way to alleviate the stressors of transnational marriage would be to allow for gendered autonomy vis-à-vis intimate flexibility. Rather than maintaining prohibitions on womens' bodies, new conceptions could include allowances for mutual sexual exploration.

Men who expect fidelity from their wives may be able to ensure this standard through their networks of kin. Methods of communication figure prominently in the struggle to maintain power. Boehm elucidates how men maintain control over their wives from abroad by using "other males, phone calls, threats and chismes [gossip]"(2008:25). The "other males" in this quote could be the brothers or older sons who are asked to keep an eye on women's whereabouts and report on what they are doing. To maintain transnational connections people use phone calls in different ways. Important to note is the way that people strategically utilize them to communicate dissatisfaction with a spouse. This transnational circulation of communication is effective at influencing behavior. As Pribilsky explains, "If, through gossip coursing through the transnational community, a migrant hears that his wife has been unfaithful he might skip his routine calls or delay sending his remittances, just long enough to exert his power"(2004:327). 
Women understand phone calls as a sign that they have not been forgotten about (McKenzie and Menjívar 2011). Spouses control one another in meaningful ways via communication.

We must look at how women use communication in the transnational context. Although men exploit communication to assert power over their wives, women too are strategically exercising agency via communicative gestures. As women become managers of finances, they find themselves working with their husbands to distribute the sent remittances. Pribilsky notes a female informant who actively ignored and refused to consult her husband when deciding when would be the best time to exchange currency. She said "he panicked and I let him panic for a few days... he was able to see that he needed me" (2004:328). By choosing not to include her husband in decision-making, this actor asserted her agency to decide what was right for the family. The relations of power in a transnational partnership therefore function not as a linear, one-way transaction but rather a shifting field or mosaic.

Women in Latin America, in a sense, embody the default parent. In order to ensure that their husbands continue to support them female fidelity is paramount. Abrego (2009) explains that men who discovered women committing infidelity back home cut off all ties to their spouses but also severed ties with their children. Abrego writes, "A woman who does not adhere to gendered moral expectations does not merit economic support. In these cases, they cut ties not only with the women but with the children they share as well'(2009:1080). This response to women's behavior comes from traditional gender and kinship norms, yet expanded on in the transnational context. While migration allows men the freedom to be sexually promiscuous; women hold to tighter moral and sexual standards. It is as if men connected with their children only though their wives, not through biological connections. Further, men exercise power on multiple levels: their marriage, their children, and their economic stability. 
One area of contention for anthropologists concerns the distribution of power in relationships after migration. Some scholars (Hirsch 1999, 2003, Pribilsky 2004) argue that women's increasing autonomy occurs because of their insertion into compensated labor markets. Hirsch (1999) claims that womens' roles as wage earners give them a stake in making decisions about finances and other familial matters. This could mean anything from her right to leave the house wearing pants to driving a car. Hirsch writes, "El mando, the power to give the orders, is conceptualized at some level as an economically earned right"(1999:1343). ${ }^{4}$ Thus, women must have some form of economic contribution and non-paid labor does not meet criteria for valid contribution. Mahler (1999) highlights the viewpoint of a Salvadorian migrant woman who claims that in the U.S., because women work and contribute to financing their lives, they have more power. She quotes her informant, "There [in El Salvador] the man is in charge and the wife has to do what her husband says... Here [in the United States] no"(Mahler 1999: 699). This perspective leads us to believe that women's roles shift as they enter the U.S. labor market. But, this should not paint a picture that migrant women end up completely better off after coming to the United States. And, as outlined previously, we must not think that this spatial occupation outside of the home forms a new phenomenon. Some advancements for women exist when they enter the labor market, but this does not erase all previous structures of male dominance.

The negotiations of power in intimate relationships shift transnationally. Male roles as head of household in Latin America allow the use of violence to show "he is ultimately the boss" (Hirsch 1999:1343). The violence that men exert over their wives helps men maintain empowered positions. However, women gain some power in the U.S., shifting the paradigm of female agency. Hirsch notes that in the U.S. Latin American male migrants are reluctant to hit

\footnotetext{
${ }^{4}$ El Mando in Spanish is the masculine noun form of the verb, Mandar which means: to send, to order (as in giving orders, not Pedir which means to order in a restaurant), to be in charge. Hirsch (1999:1343) does not provide this translation.
} 
their wives because they know the government can and will interfere (1999:1343). This may or may not work to allow women to feel less threatened. Although the U.S. government will interfere with cases of spousal abuse, whereas the Mexican government will not, one must realize this legal and structural protection hinges on documented status. An undocumented migrant cannot call the police on his or her abusive spouse for fear that someone will be deported. Only documented people access this U.S. legal protection. Identities allow for certain possibilities; the intersection of abused and undocumented form a social location that cannot access the same protections as documented people. It seems that women's economically productive roles do not reduce their endurance of relational inequality. Scholars note that women endure increasing responsibilities on top of the necessity to earn money outside the home. Tradition still influences the reorganization of kinship. The structure is not completely altered; rather, old norms are infused with modern alterations to meet current needs.

\section{$\underline{\text { Conclusion }}$}

Migration produces a profound set of circumstances that must be handled in contemporary ways. As international structures incite migration, migrants and their kin must reconfigure their gender and kinship arrangements. This requires molding and shifting how men and women take on the labor responsibilities of one another. In this paper, I have explored the intersections of race, class and gender, as well as immigration and documentation status with regard to transnational migrants and how they construct their lives and labor. These shifts and cultural edits are necessary for the upward mobility of transnational migrants and their families. Although considerable structural barriers prevent migrants from fully benefiting from being in the United States, coming to the U.S. is still a better option than remaining south of the U.S.- 
Mexico border. And, it should be clear how the government - acting transnationally — can create and modify the international climate.

All of the effort on the part of transnational migrants to re-imagine their identities as parents, spouses, men, and women is a practice of asserting individual agency to overcome the structural inequalities that negatively target certain demographics. This sheds light on the way people use their identities in strategic ways to meet their needs; identities become a sort of bargaining chip for success. Playing with dominant notions of kinship and gender responsibilities and norms allows people to exert greater agency in their lives. Identity, then, is not a static concept fused onto our bodies, but rather a powerful tool and method for asserting agency and meeting one's needs. 
References

Abrego, Leisy

2009 Economic Well-Being in Salvadoran Transnational Families: How Gender

Affects Remittance Practices. Journal of Marriage and Family 71: 10701085.

Boehm, Deborah A.

2008 “Now I am a Man and a Woman!": Gendered Moves and Migrations in a

Transnational Mexican Community. Latin American Perspectives 35(1):16-30.

2011 Deseos y Dolores: Mapping Desire, Suffering, and (Dis)loyalty within

Transnational Partnerships. International Migration 49(6): 95-106.

2009 "Quien sabe?": Deportation and Temporality among Transnational Mexicans. Urban Anthropology and Studies of Cultural Systems and World Economic

Development 38 (2-4): 345-374.

Buffington, Robert M.

2007 Subjectivity, Agency, and the New Latin American History of Gender and Sexuality. History Compass 5(5):1640-1660.

Butler, Judith

1988 Performative Acts and Gender Constitution: An Essay in Phenomenology and Feminist Theory. Theatre Journal 40(4): 519-531.

1993 Imitation and Gender Insubordination. In The Lesbian and Gay Studies Reader. Henry Abelove, Michele Aina Barale, and David M. Halperin eds. Pp. 307-320. New York: Routledge.

Collins, Patricia Hill

1998 It's All In the Family: Intersections of Gender, Race, and Nation. Hypatia 13(3): 62-82.

Donato, Katharine M., Brandon Wagner and Evelyn Patterson

2008 The Cat and Mouse Game at the Mexico-U.S. Border: Gendered Patterns and Recent Shifts. IMR 42(2): 330-359.

Fernandez-Kelly, Patricia and Douglas S. Massey

2007 Borders for Whom? The Role of NAFTA in Mexico-U.S. Migration. The Annals

Foucault, Michel of the American Academy 610: 98-118.

1978 Governmentality. In The Foucault Effect: Studies in Governmentality: With Two Lectures by and an Interview with Michel Foucault. Graham Burchell, Colin, and Peter Miller, eds. Pp. 87-104. Chicago: University of Chicago Press.

Gamburd, Michele R.

2008 Milk Teeth and Jet Planes: Kin Relations in Families of Sri Lanka's Transnational Domestic Servants. City \& Society. 20(1): 5-31.

Hirsch, Jennifer S.

1999 En el Norte la Mujer Manda: Gender, Generation, and Geography in a Mexican Transnational Community. American Behavioral Scientist 42(9):1332-1349.

2003 A Courtship After Marriage Sexuality and Love in Mexican Transnational Families. Berkeley, CA: University of California Press.

Hondagneu-Sotelo, Pierrette and Ernestine Avila

1997 "I'm Here, but I'm There": The Meanings of Latina Transnational Motherhood. Gender and Society 11(5): 548-571. 
Kunz, Rahel

2011 The Political Economy of Global Remittances: Gender and Governmentality. New York: Routledge.

Lamphere, Louise

2007 The Domestic Sphere of Women and the Public World of Men: The Strengths and Limitations of an Anthropological Dichotomy. In Gender Relations in Global Perspective: Essential Readings. Nancy Cook, ed. Pp. 7-16. Toronto: Canadian

Mahler, Sarah J.

Scholars Press Inc.

1999 Engendering Transnational Migration: A Case Study Of Salvadorans. American Behavioral Scientist 42(4): 690-719.

McKenzie, Sean and Cecilia Menjívar

2011 The meanings of migration, remittances and gifts: views of Honduran women who stay. Global Networks 11(1): 63-81.

Molé, Noelle J.

2010 Precarious Subjects: Anticipating Neoliberalism in Northern Italy's

Workplace.American Anthropologist 112(1): 38-53.

Moran-Taylor, Michelle J.

2008 When Mothers and Fathers Migrate North Caretakers, Children, and Child Rearing in Guatemala. Latin American Perspectives 35(4): 79-95.

Muñoz, Carolina Bank

2008 Race, Gender, and Shop-Floor Politics in Mexico and the United States. Ithaca:

Cornell University Press.

Nicholson, Melanie

2006 Without Their Children Rethinking Motherhood Among Transnational Migrant Women. Social Text 24(3): 13-33.

Ortner, Sherry B.

1989 High Religion A Cultural and Political History of Sherpa Budhism.

Princeton, NJ: Princeton University Press.

Parreñas, Rhacel Salazar

2005 Children of Global Migration: Transnational Families and Gendered Woes.

Stanford, CA: Stanford University Press.

Pribilsky, Jason

2004 'Aprendemos a convivir': conjugal reations, co-parenting, and family life among

Ecuadorian transnational migrants in New York City and the Ecuadorian Andes.

Global Networks 4(3): 313-334.

Reddy, Gayatri and Serena Nanda

2009 Hijras: An "Alternative" Sex/Gender in India. In Gender in Cross-Cultural

Perspective. Caroline B. Brettell and Carolyn F. Sargent, eds. Pp. 275-282. Upper

Saddle River: Pearson.

Rivera, David P., Erin E. Forquer and Rebecca Rangel

2010 Microaggressions and the Life Experience of Latina/o Americans. In

Microaggressions and Marginality Manifestation, Dynamics and Impact. Derald

Wing Sue, ed. Pp.59-83. Hoboken: Wiley.

Rose, Nikolas 
1999 Governing. In Powers of Freedom: Reframing Political Thought. Pp. 15-60 Cambridge: Cambridge University Press.

Schaeffer, Robert K.

2003 Chapter 9: Free Trade Agreements. In Understanding Globalization: The Social Consequences of Political, Economic, and Environmental Change, Second Edition. Pp. 217-250. New York: Rowman and Littlefield Publishers, Inc.

Stone, Linda

2014 Kinship and Gender. Boulder: Westview Press.

Strathern, Andrew and Pamela J. Stewart

2011 Kinship in Action: Self and Group. Saddle River: Pearson.

Zlolinski, Christian

2006 Janitors, Street Vendors, and Activists The Lives of Mexican Immigrants in Silicon Valley. Berkeley: University of California Press. 


\section{Acknowledgements}

First and foremost, I am honored to be the student of Dr. Michele R. Gamburd in the Department of Anthropology at Portland State University. Her critical advice and mentorship has assisted me in many ways. I will sincerely miss her as I move on to my graduate studies. I extend many thanks to Jason G. Damron. His encouragement to think of writing as a craft ultimately saved this project. In University Honors, I sincerely thank Dr. Ann-Marie Fallon for encouraging me to pursue a thesis. I would also like to thank Nora Quiros for tireless assistance with all things bureaucratic. 